\title{
Human Rights and Freedoms in the Digital Era: Problems and Perspectives of Their Establishment in the Eurasian Space
}

\author{
Baranov Pavel Petrovich ${ }^{1}$, Mamychev Aleksei Yurievich ${ }^{2}$, Mordovtsev Andrei Yurievich ${ }^{3,4}$, Soloviev Oleg \\ Vyacheslavovich $^{5} \&$ Gnatovskaya Elena Nikolaevna $^{6}$ \\ ${ }^{1}$ Russian Presidential Academy of National Economy and Public Administration, Rostov-on-Don, Russia \\ ${ }^{2}$ Department of Theory and History of Russian and Foreign Law, Vladivostok State University of Economics \\ and Service, Vladivostok, Russia \\ ${ }^{3}$ Department of Theory and History of State and Law, Rostov Institute (Branch) of the All-Russian State \\ University of Justice, Russia \\ ${ }^{4}$ Department of International Law, Rostov Branch, Russian State University of Justice, Russia \\ ${ }^{5}$ Department of Political Science and Ethnopolicy, Russian Presidential Academy of National Economy and \\ Public Administration, Southern Russian Institute of Management - Branch, Russia \\ ${ }^{6}$ Primorye State Agricultural Academy, Department of Philosophy and Social-Humanitarian Disciplines, Russia \\ Correspondence: Mamychev Aleksei Yurievich, Department of Theory and History of Russian and Foreign Law, \\ Vladivostok State University of Economics and Service, Vladivostok, Russia. E-mail: mamychev@yandex.ru
}

Received: October 11, 2019 Accepted: November 6, 2019 Online Published: November 28, 2019

doi:10.5539/jpl.v12n4p93 URL: https://doi.org/10.5539/jpl.v12n4p93

The study was carried out with the financial support of the Russian Foundation for Basic Research in the framework of research project No. 19-011-31031

\begin{abstract}
The article touches upon the process of transformation of a socio-political organization in the legal system, caused by integration of digital technologies and autonomous algorithmic systems. It is justified that the development of machine education and artificial intelligence systems can result in human suspension from taking important social and political decisions. Impermeability and fluidity of modern digital technologies provides hidden functioning mode of the latter, whilst their specificity is not included in the formulated agenda, creating and taking managerial decisions or planning everyday life activity. The article proves that the aftereffects of the fourth technological revolution claim for returning of the human rights standards, freedoms and legal interests as the leading form of a reference point in the global digital rivalry and in the development of certain social systems, also the necessity to establish a distinct system of human rights guarantee and human safety in the era of developing principally new digital relations is proved. Meanwhile, digital information legislation needs systematization and a strict consistent state.
\end{abstract}

Keywords: state, politics, law, artificial intelligence, robots, the fourth industrial revolution, digital technologies

\section{Introduction}

Modern sociopolitical organizations, economical and legal systems in the Eurasian space are being transformed under the influence of the society becoming more and more digital. Difficulties in predicting these processes are evident, they are mostly connected with impermeability and fluidity of modern algorithmic systems and digital technologies ${ }^{1}$. Neither politicians nor lawyers or managers, and no ordinary people possess all necessary competences in the field of modern innovations constantly introduced in our life, in specificity and nuances of the functioning of digital devices and autonomous algorithms. Moreover, in the majority of cases the mentioned specificity and nuances are not included in the formulated agenda, in creating and taking managerial decisions or

\footnotetext{
${ }^{1}$ Pasquale F. (2015). The Black Box Society: The Secret Algorithms Behind Money and Information. Cambridge, MA: Harvard University Press; Baranov P., Mamychev A., Mordovtsev A., Danilyan O., Dzeban A. (2018). Doctrinal-legal and ethical problems of developing and applying robotic technologies and artificial intelligence systems (using autonomous unmanned underwater vehicles). National Academy of Managerial Staff of Culture and Arts Herald № 2. pp. 465 - 472.
} 
in planning everyday life activity. Even state decisions are taken with the reference to the recommendations and instructions given by IT experts. Though the latter in turn are losing their power because of constant development of machine education and systems of artificial intelligence, which can result in suspension of people from taking any important for them and for the society decisions ${ }^{2}$.

From this point of view it is becoming more and more difficult to understand whether digital technologies autonomous algorithmic systems work in correlation with universal legal norms and principles, whether human rights and freedoms are taken into consideration while their creation and introduction, whether ethnic standards, values and regulatory systems created by people of a certain society are basic for them. Moreover, these "algorithms are created by those who are not be accountable to anyone except their own clients and customers, and the instruments they produce are assessed only with the help of such minimal criteria which are enough just to see that they work. We must understand what is happening in reality: it is unprecedented intrusion of small groups of unaccountable to anyone actors into the structure of chances and their distribution in life"

Of course, today innovative digital technologies and algorithmic systems know much more about us, than we know about them, their influence on our public and everyday life is enormous/ year after year it' becoming even bigger. If in earlier times a man being a complex system of biological algorithms, unique life processes, subjective behavioral models and emotional reactions functioned like a "black box", in the period of human sciences development he became an open and regulated system ${ }^{4}$. Nowadays autonomic digital algorithms and digital technologies are so called "black boxes" both for a man and for science. Posthumanistic epoch integrates not only our values, rights and freedoms, but also the necessity of creating circumstances for intensive development of algorithmic digital technologies and elaboration of digital technologies into sociopolitical agenda.

The latter demands rethinking of "the accomplished technological revolution", , returning the former standards of human rights, freedoms and legal interests in the form of a leading reference point in the global digital rivalry and in the development of certain social systems. The question is how to combine the operative value normative regulators and the developing digital culture, how to guarantee human rights and to provide human security under the circumstances of the developing fundamentally new digital relations, within which digital parties will become agents and soon after that leading actors (that is acting creatures). These questions are to be put and settled at present moment.

\section{The Survey of Slants, Researching Views and Legal Basics of Regulation}

The problems of digitalization of the environment are more and more often becoming the subject of research for representatives of psychological, sociological and political science ${ }^{6}$. Representatives of law science also pay attention to this problem. The most frequently discussed aspects are defense of intellectual rights, safety of personal data, ways of introducing automation in law-making and enforcement, modernization of methods of public regulation and impact on society, ways of defending digital public infrastructure and so on $^{7}$. Under the circumstances of growing state ambitions in the sphere of virtual space control such issues as inviolability of the citizens' private virtual life, privacy of correspondence and phone calls, freedom of speech on the Internet and some other aspects are getting special attention ${ }^{8}$.

The problem of full-fledged implementation and security of human rights and freedoms in the digital era, in the virtual and digital space in particular, demands special attention ${ }^{9}$. In modern law science the idea of so called "digital rights" is gradually developing ${ }^{10}$. Special attention to it was given by representatives of constitutional rights science. Thus, Chairman of the Constitutional Court of the Russian Federation V. D. Zorkin mentions that personal digital rights appear during the process of particularization both on the level of law-making and on the

\footnotetext{
${ }^{2}$ Bolduin P. (2018) Great convergence: information technology and new globalization. Moscow, Publishing House "Delo" RANEPA,

${ }^{3}$ Greenfield A. (2018). Radical technology: organization of everyday life. Moscow, Publishing House "Delo”, p. 330.

${ }^{4}$ Kaku M. (2018). Future of the mind. . Moscow, Alpina non-fiction,

${ }^{5}$ Shvab K. (2019). The fourth industrial revolution. Moscow, Publishing House Exom,

${ }^{6}$ Menthe Darrel, (1998) Jurisdiction In Cyberspace: A Theory of International Spaces 4 Mich.Tel.Tech.L.Rev.3 April 23, URL: https://repository.law.umich.edu/cgi/viewcontent.cgi?article=1163\&context=mttlr

7 Johnson David R. and Post David G. (1996) Law and Borders-The Rise of Law in Cyberspace. Stanford Law Review, vol. 48, 1367, pp.1378-9.

${ }^{8}$ Larina E. S., Ovchinsky V. S. (2018). .Artificial Intelligence. Big data. Crime. Moscow, Book world,

${ }^{9}$ Ovchinnikov A. I. , Mamichev A. Yu., Baranov P. P. (2018). Fundamentals of National Security. Moscow, RIOR INFRA-M,

${ }^{10}$ Baranov P., Mamychev A., Ovchinnikov A., Petruk G., Krupnitskaya V. (2017). Interdisciplinary and "postdisciplinary" approaches in the archetypal studies of the public-power organization of society. Man in India. Volume: 97. Number 23. pp. 375 - 387.
} 
level of enforcement of universal human rights in the sphere of digital and virtual space ${ }^{11}$.

Improvement of the system of state guarantees and constitutional rights and freedoms of a person and a citizen in the information sphere is announced to be one of the purposes for realization of the Russian state program "Information society (years 2011-2020)"" . In connection to this it is necessary to mention that some authors consider these rights to be information rights ${ }^{13}$. In the mentioned case information is viewed not traditionally, as some facts and knowledge transmitted from one individual to another, but as the way of processing and systematization of rather big pieces of data, which presents the basis of modern digital Internet access technologies.

On the other hand, considering the opportunity of Internet access and using it as a way of getting and transmitting information, as a way to realize a constitutional right of freedom to search for, to give, to produce and to disseminate information using any legal way (part 4, article 29), any other rights and freedoms, regulating mutual relations between a person and a state (article 23, article 24 and others) it is important to accept that such attitude to the mentioned group of rights is quite logical. However, it should be remembered that this sort of human activity, in the virtual space in particular, is quite possible in an offline regime. Moreover, understanding of the global digital net as a way of getting and giving information has become a part of the past. Modern global digital infrastructure is not limited by communication tasks any longer.

It was quite unexpected to see that the category "digital rights" was introduced into juridical circulation in the meaning which is far from that suggested by representatives of constitutional science. This is about adoption of the Federal law № 34-FL dated by 18.03.2019 "On alteration in parts one, two and article 1124 of part three of Civil Code of the Russian Federation"14. Experts of reference information system Consultant Plus explain that this document was necessary in order to "prepare Civil Code of the Russian Federation for the following adoption of laws about digital financial assets (cryptocurrency and tokens) and about crowd funding (attraction of investments through electronic platforms)",15.

In accordance with these changes "digital rights are considered to be those mentioned in the law obligatory and other rights the contents and conditions of which are defined in accordance with the rules of the information system based on the features accepted by the law". In this case this can be about the block chain technology. So, the question of how to call the suspended group of rights, arising as a result of concretization of constitutional rights and freedoms of people and citizens in digital, information, virtual space is still not settled. However, in our opinion, a supposed discussion on this topic is going to be heated and it will touch upon not only the issues of terminology, but also the problem of conceptual and of general theoretical character. As for modern Russian law-makers, they mostly prefer to use the adjective "informational" in this context.

It is necessary to say that a set of such specifying rights (digital, informational) can be various for different authors and it is not surprising. Judging from understanding digital rights as rights specifying basic rights and freedoms in the digital virtual space it is possible to admit that a significant part of constitutional rights of a person and a citizen will have its digital interpretation. Constitutional right to association (article 30) will be specified on the level of internet communities, social nets, thematic groups in social nets and others. The right to apply collective electronic petitions will specify the constitutional right of personal application; it will also direct individual and collective applications to government bodies and to local self-governing bodies (article 33). The right to health and medical service (article 41, part 1) can be specified by the right to electronic appointment to the doctor through the official portal of medical service and so on. The constitutional right to education (article 43, part 1) involves the right to distance education and so on. This list could be continued, though it should be emphasized that not all of the mentioned rights have received sufficient development and fixation on the level of sectoral legislation.

\footnotetext{
11 Zorkin V. D. (2018). Law in the digital world. Russian newspaper. 30 May. [Electronic resource]. Access mode: http://alrf.ru/news/pravo-v-tsifrovom-mire-vystuplenie-valeriya-zorkina-na-pmyuf/

12 Decree of the Government of the Russian Federation, 15.04. 2014 N 313 (red. 02.02. 2019) "On approval of the state program of the Russian Federation“ Information Society (years 2011 - 2020 )” Meeting of the legislation of the Russian Federation. 05.05.2014. № 18 (part II). Art. 2159

${ }^{13}$ Kolesnikov E. V. (2019). Development of information rights of citizens in the Russian Federation and the Republic of Kazakhstan: constitutional aspect. Russian justice. № 1. P. $13-16$.

${ }^{14}$ Federal law from 18.03.2019 № 28-FL “On Amendments to the Code of the Russian Federation on Administrative Offenses" Meeting of the legislation of the Russian Federation. 25.03.2019. № 12. Art. 1218.

${ }^{15}$ From October 1, 2019, digital rights will appear in the Civil Code of the Russian Federation // Reference legal system "Consultant Plus". [Electronic resource]. Access mode: http://www.consultant.ru/document/cons_doc_LAW_320475/
} 


\section{Main Part}

The task of formulating a complete and comprehensive list of digital rights appears to be very difficult to achieve at the current moment. In this article attention is focused not only on those digital rights that could appear as a result of global digital revolution, but also on the rights protection of which has become extremely important because of more additional ways both to provide and to break them.

Firstly, we will underline the right to the use of different electronic computing devices including those and communication devices working on the basis of the Internet. They haven't received any fixation as a system in the Russian current legislature yet and they are still on the stage of theoretical development. However, it is already possible to claim that they can be infringed by a manufacturer, a seller, a provider, a mobile operator, an intruder and also by the state and its representatives. It is also important to mention the right to inviolability of the private information environment which can be violated in the process of spreading annoying advertisement, spam, virus attacks and so on.

In the modern world the right to defense of digital intellectual rights is attracting more and more attention. There is no doubt that the development of digital technologies has made the problem of copyright infringement on the Internet in particular one of the most actual problems of the modern law science. It touches upon both traditional objects of copyright - "works of science, literature and art without reference to their merits and purposes and to the expressive means", but also "computer programs which are defended as literary works' in accordance to part 1 of article 1259 of Civil Code of the Russian Federation ${ }^{16}$. A big number of scientific works are devoted to the problem of intellectual rights defense. Without making complete analysis of this problem our main task we want to mention the fact that the only way to suppress distribution of pirated content on the Internet is blocking of corresponding websites of so called "anonymizers" whose owners don't fulfill their duties on limiting access to conforming websites ${ }^{17}$.

However, legal liability for using "anonymizers" by certain users is not provided, and there is no technical possibility "to agree" with the owners of one of the most popular anonymous networks "Tor", for example, that gave some authors a possibility to claim that the majority of the state attempts in this direction just contributed for the raise of technical computer literacy of the citizens. As time shows, in the field of copyright protection a huge role belongs to copyright holders themselves and to official distributors of licensed copyright content. Ability to formulate and to offer variants of using copyright objects available for the citizens becomes the most important stimulus for purchasing licensed products.

We can't but mention the right to creating and publishing digital information, the right to access to it. This right specifies the issues of part 1 and part 4 of article 29 of the Constitution of the Russian Federation and also some issues of other articles of the Basic Law. In accordance to this it is important to mention that the right to information realized with the help of the newest digital technologies is enriched with new forms of implementation and support. For a long time the Internet was the sphere which was completely free from censorship (in the broad sense of the term), however lately the Russian state has begun to pay more significant attention to the problem of restrictions on freedom of speech in the virtual networks introducing new additional legislative prohibitions and tightening legal liability for their violation.

In connection to this novels of the Russian legislation are actively discussed. These are the laws which are urged to put spread of information and communication of people in the virtual space under the state control, in particular spread of "information expressed in a vulgar form and offending human dignity and public morality, lack of respect to the society, state, official state symbols of the Russian Federation, the Constitution of the Russian Federation or to bodies realizing the state power in the Russian Federation" is considered to be "petty hooliganism" ${ }^{18}$. Without going into detail of the corresponding discussion, which is well known to everyone and touches upon both lawmaking directly and law enforcement aspects of this problem, we will only mention that from the point of view legal technology this wording can hardly be called successful. Similar changes in the part concerning blocking related resources were made in the Federal law "On information, information technologies and about information protection". Not less number of discussions in the context of providing constitutional right to privacy of correspondence, telephone calls, telegraph messages and others were provoked by the earlier

\footnotetext{
${ }^{16}$ Civil Code of the Russian Federation (part four) 18.12.2006 № 230-FL )red. 23.05/ 2018) Meeting of the legislation of the Russian Federation. 25.12.2006. № 52 (part 1). Art. 5496.

${ }^{17}$ Federal law from 27. 07.2006 № 149-FL (red. 18.03.2019) "About information, information technology and information protection" Meeting of the legislation of the Russian Federation. 31.07.2006. № 31 (part 1). Art. 3448.

${ }^{18}$ Federal law from 18.03.2019 № 28-FL “On Amendments to the Code of the Russian Federation on Administrative Offenses” Meeting of the legislation of the Russian Federation. 25.03.2019. № 12. Art. 1218.
} 
established demands for telecom operators to keep text messages of users up to six months since the moment of their getting, sending, delivering and processing ${ }^{19}$.

The rights consigned to provide implementation of constitutional principles in the field of democratic structure of the Russian state are a rather isolated group of digital rights. The category of "electronic democracy" is confidently coming in constitutional use ${ }^{20}$. Forms of "electronic" participation of citizens in state administration (public discussions of projects of normative legal acts, different forms of political activity, providing feedback between voters and their chosen ones and so on are being developed ${ }^{21}$. In the context of realization of the electoral rights of citizens and preparation of the project of the election code and the development of possible legal ways of remote electronic voting a new problem arises and demands more attention, that is the problem of electronic identification of a person, which is aimed to making a voting procedure easier and to raising electoral activity of Russian people, but is not perfectly technically developed yet ${ }^{22}$.

While digital rights attract vast attention of the scientific community, not less attention is given to the right to protection of personal digital data, the right to protection of an honest name of the digital person, the right to protection of personal life of a consumer including personal data processing and so on. It is also necessary to mention the fact that during the last decade there has appeared a strong tendency to shift many law enforcement right guaranteeing functions of the state into the digital sphere. The latter circumstance also lets speak about the possibility of excretion of special digital rights functioning as guarantees in relation to other rights given in the text of the Constitution of the Russian Federation.

One of the conceptual problems in the era of digital heyday is that of "virtual" and "real" in the right. It is not a secret that a significant part of a modern person's life (consumer), and of the society and the state takes place in the virtual space. Judging from the importance of constitutional issues about the right to private property (part 1, article 8, Constitution of the Russian Federation) and the right to work (article 37, Constitution of the Russian Federation) it is possible to say that special attention should be given to the problem of virtual property and the problem of virtual earnings which is closely connected with the previous one. Nowadays a huge number of people invest their time and resources in "upgrading" of their virtual accounts in different sort of computer games.

Is it possible to accept resources accumulated on the Internet as full-fledged personal property, as private property of a person, to accept a game as full-fledged work? It is considered that practice of real earnings for in-game property is mostly spread in a popular shooter "Counter-Strike: Global Offensive". This game is a good example giving a possibility to see the principles of property trade when the property was accumulated while playing a game. Skins (graphic design of this or that element of the game) are the main commodity. The process of getting skins is very simple - they fall out of in in-game safes which appear during the game. Correspondently, the more you play, the more chances to get an expensive skin and to sell it you have. In spite of the fact that skins don't influence weapon indicators, but influence only weapon design, the most uncommon of them cost several thousand dollars. And though in the "Steam" itself purchases can be made only in game currency, there are a lot of trade platforms for selling game inventory.

Such a system demonstrates the fact that in the modern world a person can really invest time and power in games using them as the "main" place of work, earning money and getting real material profit. Some games are becoming an ideal platform not only for advertising, but also for hiring virtual workforce. Those players who don't want to spend their working time on getting this or that resource (object) employ other players for doing this work, after which they pay them real money.

There are organizations employing large groups of workers for doing some mechanic work on free accounts in games aiming to get valuable resources and after that to sell them. Such workers are called "farmers" and being simple workers they are paid very little money. For the same purpose the players create "bots" whose task is

\footnotetext{
${ }^{19}$ Federal law from 06.07.2016 № 374-FL “On Amendments to the Federal Law“ On Countering Terrorism ”and certain legislative acts of the Russian Federation regarding the establishment of additional counter-terrorism measures and ensuring public safety" Meeting of the legislation of the Russian Federation. 11.07.2016. № 28. Art. 4558.

${ }^{20}$ Antonov Y. V. (2016). E-democracy as a constitutional legal phenomenon State power and local government. № 11. pp. 13 - 17; Pavel Baranov, Aleksey Mamychev, Andrey Plotnikov, Svetlana Vershinina, Tatyana Mychak (2018). Interactive communication and modernization technologies of governmental administration in modern society: main contradictions and direction of development. Herald NAMSCA. № 2. pp. 458-464.

${ }^{21}$ Constitutional and legal policy of modern Russia: ideas, priorities, values, directions: monograph / P. P. Baranov, A. I. Ovchinnikov, A Yu. Mamychev [and others.]. (2019). Moscow, RIOR: INFRA-M,

${ }^{22}$ Kartshiya A. A. (2017). Digital imperative: new technologies create new reality. IP. Copyright and related rights. № 8. P. 17 - 26.
} 
fundraising, which is rather tiresome. Actions like these can be taken in such games as "Guild Wars 2". Dozens of platforms let people sell their earned in-game inventory, but some of them sell even their accounts. An experienced gamer doesn't need much time to develop a character in an online game, after that he issues an account for sale, which gives another player a possibility to start a game without tiresome mechanic actions, with accumulated in-game currency and with powerful parameters.

Now it is reasonable to claim that a part of personal property goes into the virtual space. Over time more and more people will be involved into the process of earning money with the help of games, because due to the big number of modern and proven platforms this process has become convenient and safe as much as possible. Meanwhile, there always will be a danger that an online game will suddenly "disappear" forever, leaving gamers without their accumulated money and resources. Thus, nowadays the sphere of virtual earnings and virtual property should be regarded as one of priority areas of legal regulation.

Also, the development of problems connected with the idea of providing artificial intelligence and robotics created on this basis with some elements of legal personality is still on the theoretical level. As some researches notice, "in the sphere of legal regulation there appear relations in which a new digital personality - a robot becomes if not a subject, but at least a participant" ${ }^{\prime 23}$. From our point of view, the top priority task here is the development of conceptual approaches and generalizations which will be used as the basis of the future federal law about robotics and those changes which will touch upon sectoral legislation. Justification of these principles can touch upon revision of some issues of general theory of law connected first of all with legal theory, including aspects of legal capacity of subjects and objects of legal relations, legal facts and their classification and so on ${ }^{24}$.

Issues of cybersecurity are also rather actual. In order to solve the tasks providing sustainable functioning of different management information systems in case of computer attacks on July 26, 2017 a Federal law № 187FL "On safety of the critical information infrastructure of the Russian Federation" was adopted and it came in force on January $1,2018^{25}$. Without any doubt there is an objective necessity of security enhancements for databases of objects of property, bancs, tax service, pension funds and others in order to prevent personal data leakage.

\section{Conclusions.}

The discussed above issues don't present a complete list of actual problems and challenges that raise as a result of informatization, digitalization and virtualization of the environment. In this regard we will emphasize the importance of integrated understanding of the whole block of issues related to these problems and ways of their further development. It is impossible to solve them by momentary and punctuate legal regulation of specific rights and their guarantees. Digital Information Law needs systematization and bringing into a harmonious, consistent state. One of possible variants of such systematization could be adoption of the Information Code of the Russian Federation the project of which was prepared by the Institute of State and Law RAS in 2014.

New digital reality demands new understanding of the whole legal regulation mechanism and, what is more important, new understanding of right in a rapidly changing digital society. Full provision of constitutional human rights and freedoms in the information sphere not only demands constant and thorough work to "lead" in the legal system, but also supposes the development of relevant scientific approaches of a conceptual nature which wouldn't be limited by another system of bans, but would be based on socially and politically determined balance of private and public interests.

\section{Copyrights}

Copyright for this article is retained by the author(s), with first publication rights granted to the journal.

This is an open-access article distributed under the terms and conditions of the Creative Commons Attribution license (http://creativecommons.org/licenses/by/4.0/).

\footnotetext{
${ }^{23}$ Khabrieva T. Y., Chernogor N. N. (2018). Law in Digital Reality. Journal of Russian law. № 1. pp. 85-102.

${ }^{24}$ Baranov P. P. (2018). Legal Regulation of Robotics and Artificial Intelligence in Russia: some approaches to solving the problem. North Caucasian Legal Bulletin. № 1. P. 39-45

${ }^{25}$ Federal law from 26 July, 2017. № 187-FL “On the security of critical information infrastructure of the Russian Federation” Meeting of the legislation of the Russian Federation. 31.07.2017. № 31 (Part I). Art. 4736.
} 